\title{
STATUS NEGARA ISLAM DAN NEGARA KAFIR: PANDANGAN ULAMA KONTEMPORARI
}

\author{
Abdul Hakim Bin Baharudin @ Ismail \\ Jabatan Syariah dan Undang-Undang, Fakulti Pengajian Peradaban Islam, Kolej \\ Universiti Islam Antarabangsa Selangor, Malaysia. Tel: (60) 0139339749. Email: \\ abdulhakim@kuis.edu.my.
}

\begin{abstract}
ABSTRAK
Perbezaan status antara negara Islam dengan negara kafir telah dijadikan asas kepada perbincangan para ulama terdahulu pada banyak hukum dan tajuk dalam ilmu fiqah. Tidak kurang juga permasalahan ini dibahaskan oleh sesetengah pihak dengan tujuan mengaitkannya dengan perbincangan politik setempat. Biarpun ianya telah dibahaskan oleh kebanyakan para ulama terdahulu dalam menentukan ciri dan definisi sebenar negara Islam dan kafir, ulama kontemporari tidak terlepas daripada menyentuh persoalan ini, terutamanya menilai semula kesesuaian pembahagian negara-negara di dunia kepada Islam dan kafir dalam konteks semasa. Pandangan beberapa orang ulama yang menjadi rujukan utama umat Islam kini dihimpun dan dianalisis untuk memahami pendirian mereka terhadap persoalan ini. Hasil daripada analisis yang dilakukan, terdapat perbezaan pandangan antara mereka danpandangan mereka disesuaikan mengikut realiti dan keperluan semasa.
\end{abstract}

Kata kunci: Negara Islam, Negara kafir, Ulama, Kontemporari

\section{(STATUS OF ISLAMIC AND NON ISLAMIC STATES: VIEWS ON CONTEMPORARY MUSLIM SCHOLARS)}

\begin{abstract}
The separation between Muslim and non-Muslim countries became fundamental in Muslim scholars' views on various Syariah laws. On the other hand, some Muslims exploit this issue to support their local political views. The contemporary scholars look over to this issue, especially to review the compatibility of two-fold countries implementation in this age after it had been discussed by traditional scholars in definition and features aspects. Today's views from well-known contemporary scholars have been highlighted and analyzed to know their standings in this issue. As a result, the analysis shows that these scholars have different views on this issue, and the distinction is according to reality and current necessity.
\end{abstract}

Keywords: Islamic state, non-Muslim state, Scholars, Contemporary 


\section{Published by Faculty of Islamic Civilization Studies, KUIS}

\section{Pengenalan}

Pembahagian dunia kepada negara Islam dan negara kafir atau perang (Harb) dalam perbincangan Fiqh Islam telah diterima oleh kebanyakan para ulama terdahulu. Ini kerana, realiti yang berlaku pada ketika itu sememangnya memisahkan antara sebuah negara Islam yang diiktiraf dan negara-negara bukan Islam yang lain. Ada yang membahagikan negara-negara dunia kepada negara Islam dan kafir sahaja manakala sebahagianyang lain membahagikannya kepada tiga; iaitu negara 'Ahd sebagai negara ketiga kerana mengiktiraf hubungan damai antara negara kafir dan negara Islam.

Namun begitu, selepas berlakunya perubahan terhadap hubungan antara negara-negara dunia yang juga melibatkan negara umat Islam,iaitu dengan kewujudan perjanjian damai antara negara-negara dantertubuhnya Pertubuhan Bangsa-bangsa Bersatu, status pemisahan negara Islam dan kafir perlu dilihat semula. Ulama kontemporari telah memberikan pandangan terhadap isu ini. Sebahagiannya melihat asas pemisahan ini perlu diterima pakai sehingga kini manakala sebahagian yang lain memberikan penilaian semula bersesuaian dengan situasi kini.

\section{Metodologi Kajian}

Kajian ini ialah kajian kualitatif iaitu dengan dilakukan pencarian dan penelitian terhadap pandangan beberapa orang ulama kontemporari terhadap status negara Islam dan kafir mengikut realiti semasa. Antara pandangan ulama yang diberikan perhatian ialah Yusuf Al-Qaradawi, Wahbah Al-Zuhayli, Abdullah bin Bayyah serta beberapa ulama dan penulis yang lain yang turut membincangkan isu ini seperti Ismail Lutfi AlFatani.

\section{Negara Islam, Kafir (Harb) Dan 'Ahd}

Umumnya, ulama telah memperkenalkan tiga jenis negara walaupun ada yang hanya mengiktiraf dua jenis sahaja. Negara Islam dan negara kafir ialah asas dalam perbezaan status negara yang merujuk kepada permusuhan golongan kafir kepada Islam. Manakala negara 'Ahd ialah negara kafir pada asalnya tetapi mempunyai ikatan perdamaian dengan negara Islam. Berikut ialah definisi dan ciri-ciri bagi setiap jenis negara tersebut.

\subsection{Negara Islam dan Kafir}

Pelbagai definisi serta ciri-ciri telah diketengahkan oleh para ulama untuk menentukan status negara Islam serta garis pemisah antara negara Islam dan kafir. Pandangan yang berbeza-beza ini menggambarkan sudut pandang yang berbeza oleh para ulama dalam melihat hakikat sebuah negara Islam. Antara pandangan-pandangan tersebut, ialah:-

- Mengikut Al-Kasani (1986) "Ulama mazhab Hanafi tidak berselisih pendapat berkenaan perubahan negara kafir kepada negara Islam dengan sebab tertegaknya hukum Islam akan tetapi mereka berselisih pendapat berkenaan sebab-sebab negara Islam berubah kepada negara kafir. Imam Abu Hanifah menetapkan 3 syarat:

- Tertegaknya undang-undang kafir

- Berjiran dengan negara kafir

- Orang beriman dan kafir zimmi tidak mendapat keamanan 
- Ibnu Qayyim (2002): "Negara Islam ialah negara yang didiami oleh orang Islam dan terlaksana padanya hukum-hukum Islam dan negara yang tidak melaksanakannya ia bukanlah negara Islam sekalipun ia bersebelahan negara Islam".

- As-Syaukani (1985): “... sekiranya segala kuasa pemerintahan berada di tangan umat Islam sehingga orang kafir tidak dapat menonjolkan kekufuran melainkan apa yang diizinkan oleh pemerintahan Islam maka ia ialah negara Islam...".

- Ibnu Hazm (1988) pula memberikan kaedah yang umum berkenaan penentuan status sesebuah negara iaitu dengan melihat kepada majoriti penduduk dan pemerintah padanya.

- Menurut Abdul Qadir Audah (2001), negara Islam ialah sebuah negara yang menampakkan perlaksanaan undang-undang Islam atau penduduk Islam dapat menzahirkan pengamalan hukum-hukum Islam. Begitu juga dikira sebagai negara Islam bagi negara-negara yang keseluruhan penduduknya atau sebahagian besarnya adalah muslim, setiap negara yang dikuasai oleh orang Islam walaupun kebanyakan penduduknya adalah bukan Islam. Seterusnya dianggap negara Islam jika negara itu diperintah oleh bukan Islam tetapi penduduk Islam bebas melaksanakan segala perintah agama.

- Abu Zahrah (1995) ada mengatakan, negara Islam ialah negara yang perintah oleh penguasa Islam dan segala kuasa dan kekuatan adalah di tangan orangorang Islam.

Ini ialah sebahagian daripada pandangan para ulama dalam menetapkan definisi dan ciri-ciri bagi negara Islam. Kebanyakan mereka hanya menggariskan ciriciri bagi sebuah negara Islam manakala negara yang tidak memenuhi ciri-ciri tersebut dianggap sebagai negara kafir. Beberapa orang penulis seperti Ismail Lutfi Al-Fatani dan Muhammad Khair Haikal menilai pandangan-pandangan tersebut dan memberikan kesimpulan seperti berikut:

- Lutfi Al-Fatani (1998): Sesebuah negara itu dianggap sebagai negara Islam apabila terlaksananya peraturan Islam dan kuasa pemerintahan berada di tangan umat Islam.

- Muhammad Khair Haikal (1996): Sistem hukum yang berjalan ialah sistem Islam dan keamanan dalam dan luar negara berada di bawah kuasa umat Islam.

Setiap ciri negara Islam yang dinyatakan oleh para ulama mempunyai perkaitan antara satu yang lain. Contohnya pada syarat kepimpinan negara dikuasai oleh orang Islam dan perlaksanaan undang-undang Islam pada negara tersebut. Secara logik mudah, sesebuah negara yang melaksanakan undang-undang Islam kerana ianya dipimpin oleh orang Islam dan agak mustahil jika pemimpin bukan Islam ingin mengaplikasikan hukum-hakam Islam. Manakala sekiranya pemimpin Islam itu seorang yang amanah dan bertanggungjawab, dia akan melaksanakan segala perintah agama dengan menegakkan undang-undang Islam di atas muka bumi. 


\section{Published by Faculty of Islamic Civilization Studies, KUIS}

\section{2}

\section{Negara'Ahd}

Pada bahasa, 'Ahd bermaksud janji. Manakala pada istilah pula, terdapat beberapa pengertian yang boleh diambil, antaranya:

- Al-Kasani (1986): Perjanjian dan perdamaian untuk meninggalkan peperangan.

- Ibnu 'Arafah: Perjanjian antara muslim dan kafir harbi untuk berdamai bagi tempoh tertentu yang dia tidak dipertanggungjawabkan pada hukum Islam (Al-Khurasyi, 1997).

Berdasarkan definisi di atas, dapat difahami bahawa negara 'Ahd ialah negara yang mempunyai perjanjian damai dengan negara Islam. Walaupun pada asalnya ianya ialah negara kafir atau negara yang bermusuh malah berperang dengan negara Islam, tetapi disebabkan perjanjian yang dimeterai antara keduanya, mereka bertanggungjawab memelihara perdamaian antara satu sama lain terutamanya menghindari daripada serangan ke atas satu sama lain selagi mana dalam tempoh perjanjian.

\section{Pandangan Ulama Kontemporari}

Wahbah Al-Zuhayli merupakan antara ulama yang mendokong pandangan yang memisahkan status negara-negara dunia kepada negara aman dan perang dan bukannya negara Islam dan kafir. Negara aman yang dimaksudkan ialah negara yang selamat dan tidak terlibat dengan peperangan dan sebaliknya bagi negara perang. Pada asasnya, mereka menganggap seluruh dunia ialah sebuah negara sahaja sebagaimana pandangan Imam Syafei. Pembahagian negara Islam dan kafir oleh para ulama terdahulu adalah merupakan pandangan bersifat waqei serta tiada asas syara' dan nas.

Al-Ghunaimi menyatakan bahawa pembahagian ini telah diasaskan oleh fuqaha' pada kurun ke 2 hijrah iaitu di era kerajaan Abbasiyah lantaran umat Islam terkesan dengan hubungan yang wujud antara negara Islam dengan bukan Islam pada waktu itu (Yaacob, 1984). Hubungan permusuhan dan peperangan antara negara Islam dengan kafir telah menyebabkan negara-negara musuh dilabel sebagai "Dar Al-Harb" atau negara perang. Namun begitu, status perang perlulah bersifat sementara iaitu sekadar berlakunya peperangan itu, selepas berakhirnya peperangan ia tidak lagi dianggap sebagai negara perang (Al-Zuhayli, 1998).

Abdullah Bin Bayyah juga memberikan pandangan yang hampir sama dengan Al-Zuhaily apabila beliau secara jelas menyatakan aplikasi terhadap pembahagian negara Islam dan negara kafir tidak lagi sesuai dengan keadaan masyarakat dunia hari ini kerana perjanjian yang wujud diantara negara-negara ahli PBB dan cabaran globalisasi. Umat Islam hari ini telah menetap di serata dunia sehingga ke negara-negara Eropah dan membentuk komuniti Islam. Bahkan perlu disedari bahawa Islam yang dibawa oleh Rasulullah SAW adalah untuk seluruh manusia, sebagaimana firman Allah Taala dalam Surah Al-A'raf 7:158 :

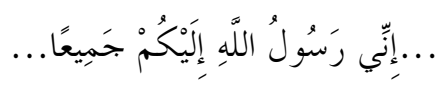

"Sesungguhnya aku adalah Pesuruh Allah kepada kamu semua". 
Oleh itu, seluruh tanah yang didiami oleh manusia perlu dibezakan dengan status "ummah ijabah" iaitu umat Islam dan "ummah dakwah" bukan Islam. Perhubungan yang wujud antara negara tidak seharusnya berasaskan kepada agama semata-mata. Umat Islam yang tinggal negara-negara bukan Islam pun membina hubungan dengan masyarakat setempat di atas dasar kemanusiaan dan toleransi.

Manakala terdapat pula sebahagian ulama seperti Yusuf Al-Qaradawi dan Ismail Lutfi Al-Fatani yang tetap mempertahankan kesesuaian pandangan ulama terdahulu dalam memisahkan negara Islam dan kafir untuk dipraktikkan pada waktu kini. Mereka berhujah bahawa pembahagian antara negara Islam dan kafir mempunyai asas syara' dan nas. Ianya berdasarkan kepada beberapa ayat daripada Al-Quran dan Hadis yang menjelaskan ciri-ciri negara Islam dan kafir atau membezakan antara kedua-duanya (Al-Qaradawi, 2010).

- Ciri negara Islam

i. Dalil Al-Quran

Firman Allah SWT:

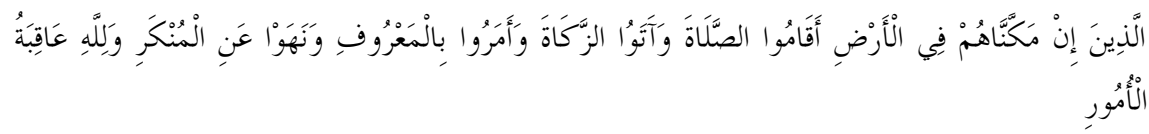

"Iaitu mereka (umat Islam) yang jika Kami berikan mereka kekuasaan memerintah di bumi nescaya mereka mendirikan sembahyang serta memberi zakat, dan mereka menyuruh berbuat kebaikan serta melarang dari melakukan kejahatan dan perkara yang mungkar.dan (ingatlah) bagi Allah jualah kesudahan segala urusan" (Surah AlHajj 22: 41).

Ayat ini menjelaskan ciri-ciri sebuah negara yang didiami umat Islam perlu didirikan sembahyang, ditunaikan zakat dan ditegakkan amar makruf dan nahi mungkar.

Seterusnya, firman Allah SWT dalam Surah An-Nur 24: 55:

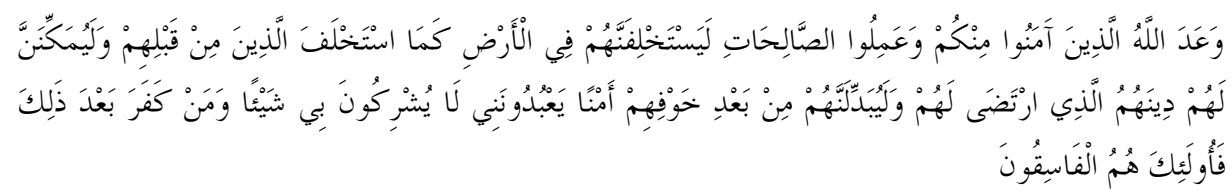

"Allah menjanjikan orang-orang yang beriman dan beramal soleh dari kalangan kamu (Wahai umat Muhammad) bahawa ia akan menjadikan mereka khalifahkhalifah yang memegang kuasa pemerintahan di bumi, sebagaimana ia telah menjadikan orang-orang yang sebelum mereka: khalifah-khalifah yang berkuasa; dan ia akan menguatkan dan mengembangkan agama mereka (agama Islam) yang telah diredhaiNya untuk mereka; dan ia juga akan menggantikan bagi mereka keamanan setelah mereka mengalami ketakutan (dari ancaman musuh). Mereka terus beribadat kepadaKu dengan tidak mempersekutukan sesuatu yang lain denganKu. dan (ingatlah) sesiapa yang kufur ingkar sesudah itu, maka mereka itulah orang-orang yang derhaka". 


\section{Published by Faculty of Islamic Civilization Studies, KUIS}

Ayat ini pula menjelaskan tiga ciri utama bagi sebuah negara Islam iaitu yang; pertama, penguasaaan oleh orang-orang mukmin, kedua, tertegaknya agama Allah dan ketiga keamanan bagi orang-orang Islam (Al-Fatani, 1998).

ii. Dalil hadis

Hadis daripada Buraidah yang menceritakan tentang wasiat Rasulullah SAW kepada panglima-panglima perang.Rasulullah SAW berwasiat kepada mereka supaya menyeru manusia kepada tiga perkara. Antara yang disebutkan oleh Baginda SAW ialah,

$$
\text { وعليهم ما على ادعهم إلى التحول من دارهم إلى دار المهاجرين وأخبرهم أهم إن فعلوا ذلك فلهم ما للمهاجرين }
$$

“... kemudian serulah mereka supaya berpindah daripada negara mereka kepada ( دار negara ahli-ahli hijrah...” (Riwayat Muslim)

Selepas manusia diseru kepada Islam dan menerimanya, mereka pula diseru supaya meninggalkan negara mereka dan berhijrah ke negara ahli-ahli hijrah yang merujuk kepada negara yang didiami umat Islam atau negara Islam.

- Ciri negara kafir

i. Dalil Al-Quran

Firman Allah SWT, Surah Al-Nisa' 4: 75:

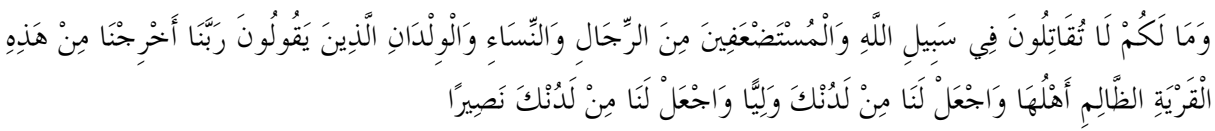

"Dan apakah yang menghalang kamu (maka kamu) tidak mahu berperang pada jalan Allah (untuk menegakkan agama Islam) dan (untuk menyelamatkan) orang-orang yang tertindas dari kaum lelaki, perempuan dan kanak-kanak. Iaitu mereka yang selalu (berdoa dengan) berkata: "Wahai Tuhan kami, keluarkanlah kami dari negeri (Makkah) ini, yang penduduknya (kaum kafir musyrik) yang zalim, dan jadikanlah bagi kami dari pihakMu seorang pemimpin yang mengawal (keselamatan ugama kami), dan jadikanlah bagi kami dari pihakMu seorang pemimpin yang membela kami (dari ancaman musuh)".

Ayat ini menggambarkan kezaliman yang melampau ke atas umat Islam di Mekah apabila disertakan doa oleh kanak-kanak, maka itulah ciri sebuah negara kafir yang dikuasai oleh pemimpin-pemimpin yang zalim.

ii. Dalil hadis

Hadis-hadis yang menggunakan istilah negara musuh dan merujuk kepada negara kafir, antaranya ialah: 
"Daripada Ibnu Umar RA: Sesungguhnya Rasulullah SAW melarang bermusafir dengan mushaf (Al-Quran) ke bumi musuh kerana bimbang ia akan sampai ke tangan musuh" (Riwayat Muslim).

- Perbezaan antara negara Islam dengan kafir

i. Dalil Al-Quran

Firman Allah SWT, Surah Al-Nisa’ 4: 92 \& 93:

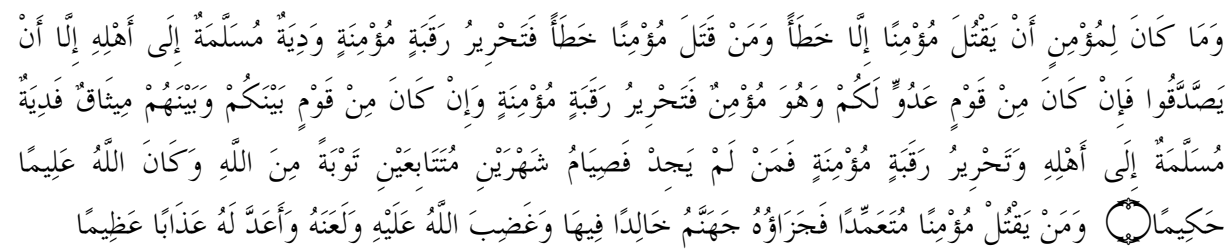

"Dan tidak harus sama sekali bagi seseorang mukmin membunuh seorang mukmin yang lain, kecuali dengan tidak sengaja. Dan sesiapa yang membunuh seorang mukmin dengan tidak sengaja, maka (wajiblah ia membayar kaffarah) dengan memerdekakan seorang hamba yang beriman serta membayar "diah" (denda ganti nyawa) yang diserahkan kepada ahlinya (keluarga si mati), kecuali jika mereka sedekahkan (memaafkannya). Tetapi jika ia (yang terbunuh dengan tidak sengaja) dari kaum (kafir) yang memusuhi kamu, sedang ia sendiri beriman, maka (wajiblah si pembunuh membayar kaffarah sahaja dengan) memerdekakan seorang hamba yang beriman. Dan jika ia (orang yang terbunuh dengan tidak sengaja itu) dari kaum (kafir) yang ada ikatan perjanjian setia di antara kamu dengan mereka, maka wajiblah membayar "diah" (denda ganti nyawa) kepada keluarganya serta memerdekakan seorang hamba yang beriman. Dalam pada itu, sesiapa yang tidak dapat (mencari hamba yang akan dimerdekakannya), maka hendaklah ia berpuasa dua bulan berturut-turut; (hukum yang tersebut) datangnya dari Allah untuk menerima taubat (membersihkan diri kamu). Dan (ingatlah) Allah Maha Mengetahui, lagi Maha Bijaksana"

Ayat di atas menjelaskan tiga keadaan dan hukum bagi kesalahan membunuh dengan tidak sengaja.

a) Membunuh orang Islam yang berada di tanah air mereka, maka dihukum membayar diat dan kaffarah.

b) Membunuh orang yang telah beriman tetapi tinggal di tempat asalnya dikalangan orang kafir yang memerangi Islam, maka dihukum kaffarah sahaja.

c) Membunuh orang Islam yang tinggal bersama kaumnya tetapi kaumnya itu mempunyai ikatan perjanjian damai dengan orang Islam maka hukumannya adalah membayar diat dan kaffarah (Al-Qurtubi, 2010).

Al-Qaradawi (2010) menyatakan, ayat di atas telah membezakan penetapan hukuman bagi kesalahan membunuh orang Islam yang tidak disengajakan mengikut perbezaan status sesebuah negara dengan yang lain. Perbezaan status sesebuah negara ditentukan berdasarkan kepada pendirian dan pegangan agama penduduknya.

Nas-nas yang menjadi dalil kepada pemisahan antara negara Islam dengan negara kafir tidaklah menjadi sandaran yang jelas bahkan ianya hanya memberikan 
Published by Faculty of Islamic Civilization Studies, KUIS

isyarat melalui ciri-ciri dan suasana yang wujud bagi setiap kategori negara. Maka tidak hairanlah sebahagian ulama berpendapat bahawa pembahagian negara Islam dan kafir tidak mempunyai asas syara' dan nas.

Melihat kepada suasana dan keperluan dewasakini, setiap negara umat Islam haruslah dianggap sebagai negara Islam biarpun sebahagiannya tidak mempraktikkan keseluruhan peraturan agama. Bahkan sekiranya sesebuah negara itu mendakwa mereka ialah negara sekular dan mengamalkan perlembagaan sekular, mereka tetap dianggap sebagai sebuah negara Islam. Sekurang-kurangnya negara tersebut ialah sebuah negara Islam yang sempurna pada asalnya atau pun pemimpin dan majoriti penduduknya adalah Islam serta tertegaknya syiar-syiar agama seperti azan, solat jamaah dan sebagainya (Al-Qaradawi, 2010).

Merujuk kepada perjanjian-perjanjian yang wujud antara negara-negara di dunia melalui PBB, Al-Qaradawi (2010) berpendapat negara-negara bukan Islam adalah termasuk dalam kategori negara 'Ahd. Perjanjian-perjanjian damai menghalang negara-negara ahli daripada berperang sesama sendiri dan negara-negara Islam perlu berpegang kepada janji-janji yang diikat. Namun begitu, ia tidak termasuk negara Israel kerana ia merupakan sebuah negara haram yang menindas dan memusuhi umat Islam sekalipun ia telah diiktiraf sebagai negara ahli.

\section{Dapatan Kajian}

Berdasarkan beberapa pandangan yang dihimpunkan, kita mendapati bahawa pembahagian negara yang dipelopori oleh fuqaha terdahulu tidak diterima secara keseluruhan oleh ulama kontemporari. Sebahagiannya hanya mengambil semangat dan ruh daripada perbezaan negara Islam dan kafir kemudian memfokuskan kepada soal keamanan dan keselamatan bagi umat Islam. Pandangan ini dilihat lebih meraikan kewujudan komuniti umat Islam di negara-negara maju dan negara bukan Islam seperti Amerika Syarikat, United Kingdom dan Perancis lantaran mereka diberikan hak, kebebasan dan keselamatan yang sewajarnya.

Manakala pandangan yang mempertahankan status negara Islam telah meletakkan ciri-ciri yang minima bagi memenuhi syarat negara Islam. Pandangan ini dapat memenuhi tuntutan penyatuan umat Islam hari ini yang berada di serata dunia dan dipisahkan oleh sempadan negara. Biarpun negara umat Islam hari ini di bina atas semangat kebangsaan, meninggalkan banyak perintah-perintah agama dan bertelingkah antara satu sama lain, sekurang-kurangnya mereka mempunyai status dan platform yang sama ke arah membentuk penyatuan umat Islam.

\section{Kesimpulan}

Islam merupakan agama yang bersifat anjal yang boleh berubah bagi memenuhi keperluan manusia. Sifat anjal ini selalu dikaitkan dengan persoalan yang berkaitan muamalah dan urusan keduniaan manusia. Pemisahan antara negara Islam dengan negara kafir merupakan ijtihad yang dapat memenuhi keperluan manusia dan membantu dalam urusan berpolitik umat Islam. Perubahan yang berlaku pada setiap zaman pastinya memberikan kesan kepada hukum dan pendekatan dalam urusan duniawi. Tidak sewajarnya ijtihad ulama terdahulu terus dijadikan pegangan sekiranya ia tidak lagi menepati suasana dan tuntutan semasa.

Umat Islam juga tidak seharusnya terus berpolemik dalam membincangkan soal status negara Islam mahu pun ciri-ciri yang perlu dipenuhi sebagaimana yang dinyatakan oleh para fuqaha. Bahkan keutamaan yang perlu diberikan oleh setiap 
individu Islam dewasa kini adalah membina kesatuan ummah di atas dasar kebenaran dan menjana kekuatan sehinggalah Islam mampu memimpin dunia.

\section{Rujukan}

Abu Zahrah, Muhammad. (1995). Al-'Alaqat Ad-Dawliyyah fi Al-Islam. Kaherah: Dar Al-Fikr Al-'Arabi.

Al-Fatani, Ismail Lutfi. (1998). Ikhtilaf Ad-Daraini wa Atharuhu fi Ahkam AlMunakahat wa Al-Muamalat. Kaherah: Dar As-Salam li At-Toba'ah wa AnNasyr wa At-Tauzi' wa At-Tarjamah.

Al-Kasani, Abu Bakar Bin Mas'ud. (1986). Badai' As-Sanai' fi Tartib AsSyarai'.Beirut: Dar Al-Kutub Al-Ilmiyyah.

Al-Khurasyi, Muhammad bin Abdullah. (1997). Hasyiah Al-Khurasyi 'Ala Mukhtasar Syayiidi Khalil. Beirut: Dar Al-Kutub Al-'Ilmiyyah.

Al-Qaradhawi, Yusuf. (2010) Fiqh Al-Jihad: Dirasah Muqaranah li Ahkamihi wa Filsafatihi fi Dhaui Al-Quran wa As-Sunnah. Kaherah: Maktabah Wahbah.

Al-Qurthubi, Muhammad bin Ahmad. (2010) Al-Jamei' li Ahkam Al-Quran. Kaherah: Dar Al-Hadith.

As-Syaukani, Muhammad Bin Ali. (1985). As-Sail Al-Jarrar Al-Mutadaffiq A'la Hadaiq Al-Azhar. Beirut: Dar Al-Kutub Al-Ilmiyyah.

Audah, Abdul Qadir. (2001). At-Tasyri' Al-Jinai: Muqaranan bi Al-Qanun Al-Wadh'i. Beirut: Muassasah Risalah.

Az-Zuhayli, Wahbah. (1998).Athar Al-Harb fi Al-Fiqh Al-Islami Dirasah wa AlMuqaranah. Damsyik: Dar Al-Fikr.

Ibnu Hazm Az-Zahiri.(1988). Al-Iisol fi Al-Muhalla bi Al-Athar. Beirut: Dar Al-Kutub Al-Ilmiyyah.

Ibnu Qayyim Al-Jauziyyah.(2002). Ahkam Ahl Az-Zimmah. Beirut: Dar Al-Kutub AlIlmiyyah.

Haikal, Muhammad Khair. (1996). Al-Jihad wa Al-Qital fi As-Siyasah As-Syar'iyyah. Beirut: Dar Ibn Hazm.

Muslim bin Al-Hajjaj. (1412H). Sahih Muslim. Beirut: Dar Al-Ihya' At-Turath Al'Arabi.

Yaacob, Md Akhir. (1984) The Law of Neutrality A Comparative Study of Islamic Law and Public International Law. Doctoral Thesis, University Malaya.

\section{Author's Biography}

Abdul Hakim Bin Baharudin, merupakan lulusan sarjana dalam bidang Fiqh dan Usul-Fiqh daripada Universiti Islam Antarabangsa Malaysia. Sebelum itu telah menamatkan pengajian di peringkat sarjana muda dalam bidang Syariah di Universiti Al-Azhar. Beliau pernah menjawat jawatan sebagai pensyarah di TATI University College dan sekarang sebagai pensyarah di Kolej Universiti Islam Antarabangsa Selangor. Boleh dihubungi melalui email berikut: abdulhakim@kuis.edu.my. 